\title{
LITOFACIÁLNÍ ANALÝZA BÁZE HRADECKO-KYJOVICKÉHO SOUVRSTVÍ (NIIZKÝ JESENÍK, MORAVSKOSLEZSKÁ JEDNOTKA ČESKÉHO MASIVU)
}

\author{
Litofacies analysis of the basis of the Hradec-Kyjovice Formation (Nízký Jeseník Mts., \\ Moravian-Silesian Unit, Bohemian Massif)
}

\author{
Aleš Novák, Tomáš Lehotský \\ Katedra geologie PřF UPv Olomouci, 17. listopadu 12, 77146 Olomouc; e-mail: ales.novak@upol.cz
}

(15-34 Vítkov, 15-41 Hlučín)

Key words: Moravosilesicum, Nízký Jeseník Mts., Hradec-Kyjovice Formation, lithofacies analysis, ichnofacies, foreland basin, Upper Viséan

\section{Abstract}

A detailed field facies and ichnofacies analysis undertaken in the eastern part of the Nizký Jesník Mts. revealed that the basal part of Hradec-Kyjovice Formation of Upper Viséan age corresponded to coarse-grained siliciclastic turbidite system. Research was focused on detailed measurement of fifteen outcrops in the area. The formation was deposited in deep water environmental of the foreland basin by sediment gravity flows. Five facies were identified in the Hradec Member of the Hradec-Kyjovice Formation: conglomerate facies, pebble to coarse grained sandstone facies, coarse grained sandstone facies, sandstone-siltstone facies and the muddy siltstone facies. The conglomerate facies, pebble to coarse grained sandstone facies and coarse grained sandstone facies represent proximal, coarse grained channel deposits of high-density turbidite currents. The sandstone-siltstone sediments consist of a variety of turbidites deposites in lobes and interchannel environments. The muddy siltstone facies were deposited in interchannel environments by lowdensity turbidite currents. Some depositional lobes contain trace fossils of the Nereites ichnofacies. Sedimentary record of the basal parts of the Hradec-Kyjovice Formation indicates a Late Viséan a change in the development of Culm basin in Upper Viséan and beginning of new sedimentary cycle of sedimentation governed presumably by a compressional tectonic pulse.

\section{Úvod}

Bazální část hradecko-kyjovického souvrství tzv. hradecké vrstvy ve smyslu Patteiského (1929) a Zapletala et al. (1989) je poměrně dobře odkryta v okolí Hradce nad Moravicí, v hluboce zařezaném údolí řeky Moravice mezi Žimrovicemi a Vikštejnským Podhradím, stejně tak v okolí Oder a na s. svahu kry Maleníku (obr. 1). Horniny spodnokarbonského stárí představují ve studované oblasti sledy hlubokomořských uloženin gravitačních proudů

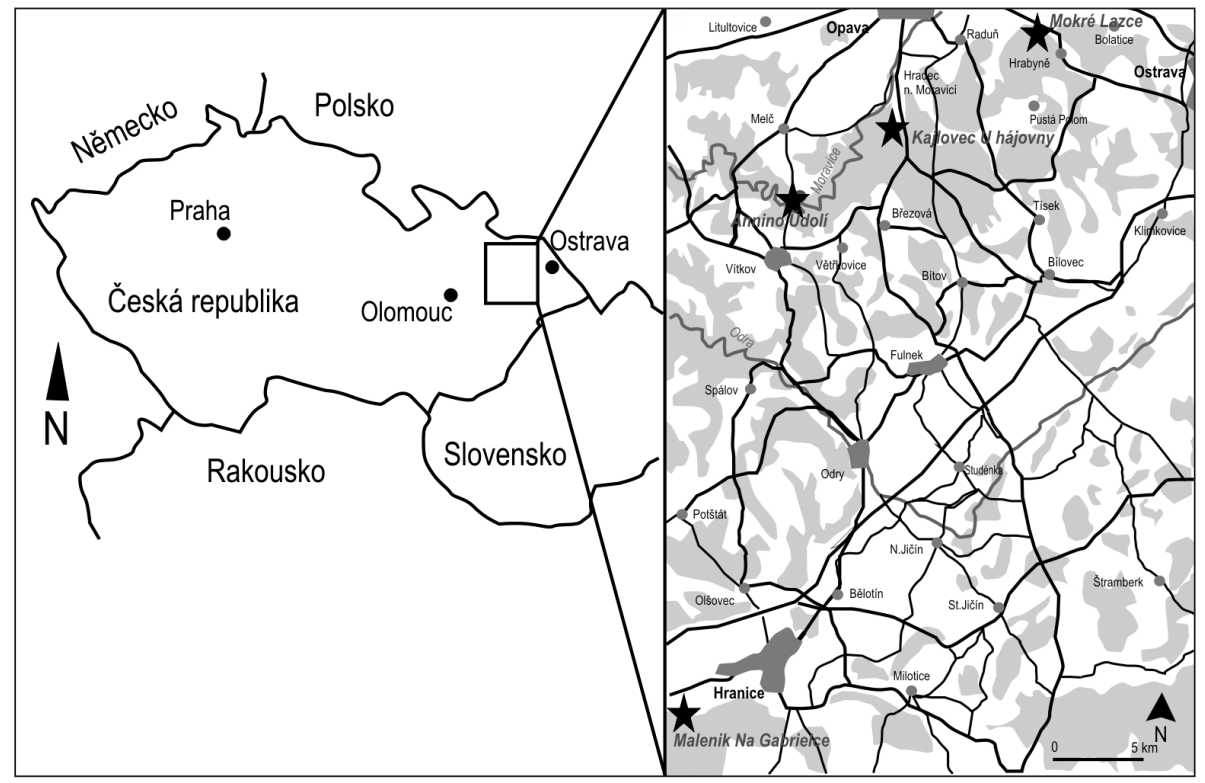

Obr. 1: Mapa studované oblasti.

Fig. 1: Map of studied area. zastoupených slepenci, drobami, prachovci a vzácněji jílovci. Transport a ukládání těchto sedimentů ovlivňovala řada faktorů, které lze interpretovat ze sedimentárních záznamů. Ukládání sedimentů gravitačními proudy významně ovlivňovalo parametry paleoekosystému v prostoru depozice. Fosilní záznamy projevů života v sedimentech mohou pomoci interpretovat ekologické podmínky v někdejší předpolní pánvi spodnokarbonského moře.

\section{Metodika}

V oblasti mezi Hradcem nad Moravicí, Mokrými Lazci, Fulnekem a Lipníkem nad Bečvou byla $\mathrm{v}$ minulém roce provedena podrobná litofaciální analýza. Výzkum studovaných profilů byl soustř̌eděn na měření mocností vrstev spolu s popisem sedimentů na základě petrografického složení a struktury. Dále byly studovány texturní prvky, jako jsou gradační zvrstvení, laminace, šikmé zvrstvení, proudové stopy, vlečné stopy, vtisky, skluzové textury, stopy po úniku vody, závalky intraklastů, intervaly Boumovy sekvence a bioglyfy. Dle takto zjištěných fenoménů byly studované 
horniny zařazeny do faciálních tříd dle Pickeringa et al. (1986). Do třídy A jsou zařazeny slepence, třídu B tvoří pískovce, $\mathrm{v}$ třídě $\mathrm{C}$ jsou směsi písku, prachu a jílu, třída $\mathrm{D}$ je reprezentována prachovci, trrída E zastupuje jílovce a exotické zdeformované vrstvy jsou zařazeny v třídě F. Mimo to byl zjištován výskyt fosilní fauny, flóry a fosilních stop.

\section{Geologická a stratigrafická situace v zájmové oblasti}

Spodnokarbonské sedimenty v Nízkém Jeseníku patří ke kulmské facii a mají typické litologické znaky flyše (Kumpera 1966). Reprezentují jihovýchodní část systému evropských variských předpolních pánví. Tyto pánve jsou vyplněny $7,5 \mathrm{~km}$ mocnými polohami sedimentů, ukládanými axiálním turbiditním systémem. Snosová oblast se nacházela jižně až jihozápadně od pánve (Hartley - Otava 2001). Nejzápadněji se v Nízkém Jeseníku vyskytuje stratigraficky nejstarší andělskohorské souvrství, které směrem do nadloží a $\mathrm{k}$ východu přechází do souvrství hornobenešovského. Tato souvrství by měla odpovídat uloženinám zbytkové flyšové pánve. Nadložní a východněji položená souvrství moravické a hradecko-kyjovické byla uložena v předpolní flyšové pánvi (Kumpera - Martinec 1995). Sedimenty byly uloženy za podmínek diktovaných trvalým kontrastem mezi vyzdvihovanou oblastí snosu a zahlubovanou flyšovou pánví. Kulmská pánev, která byla depocentrem těchto uloženin, měla protáhlý tvar a její osa směřovala od JZ k SV (Kumpera 1966, 1976, 1983; Hartley - Otava 2001). Hradecko-kyjovické souvrství je tvořeno lavicovitými až deskovitými drobami s vložkami prachovito-jílových rytmitů (Zapletal et al. 1989). Stratigraficky je zařazeno do goniatitových zón Goy a E1. Ve fosilní fauně převládají goniatiti, nautiloidi a mlži, méně četní jsou ramenonožci a zástupci jiných skupin (Kumpera 1983). Fosilní flóra je reprezentována zejména kapradinou Sphenopteris adianthoides, kořeny plavuní Stigmaria stellata, přesličkovitými rostlinami Eleutherophyllum mirable a Archaeocalamites scrobiculatus (Purkyňová 1988). Fosilní stopy jsou reprezentovány druhy Phyllodocites jackoni, Diplocraterion isp., Cosmoraphe kettneri, Dictyodora liebeana a Cosmoraphe dvoraki (Zapletal - Pek 1987). Bázi souvrství tvoří stratigraficky nižší člen - hradecké droby (Gilíková et al. 2003). Celková mocnost hradeckých drob se odhaduje na 800 metrů. Kumpera (1983) je charakterizuje jako mocný flyšový sled, často s vložkami prachovců a břidlic, které tvoří nadloží moravického souvrství. Jedná se převážně o lavicovité, jemně až hrubě zrnité droby s vložkami a čočkami slepenců. Tato konglomerátová tělesa jsou označena jako nýtecký slepencový obzor a jsou

\section{a}
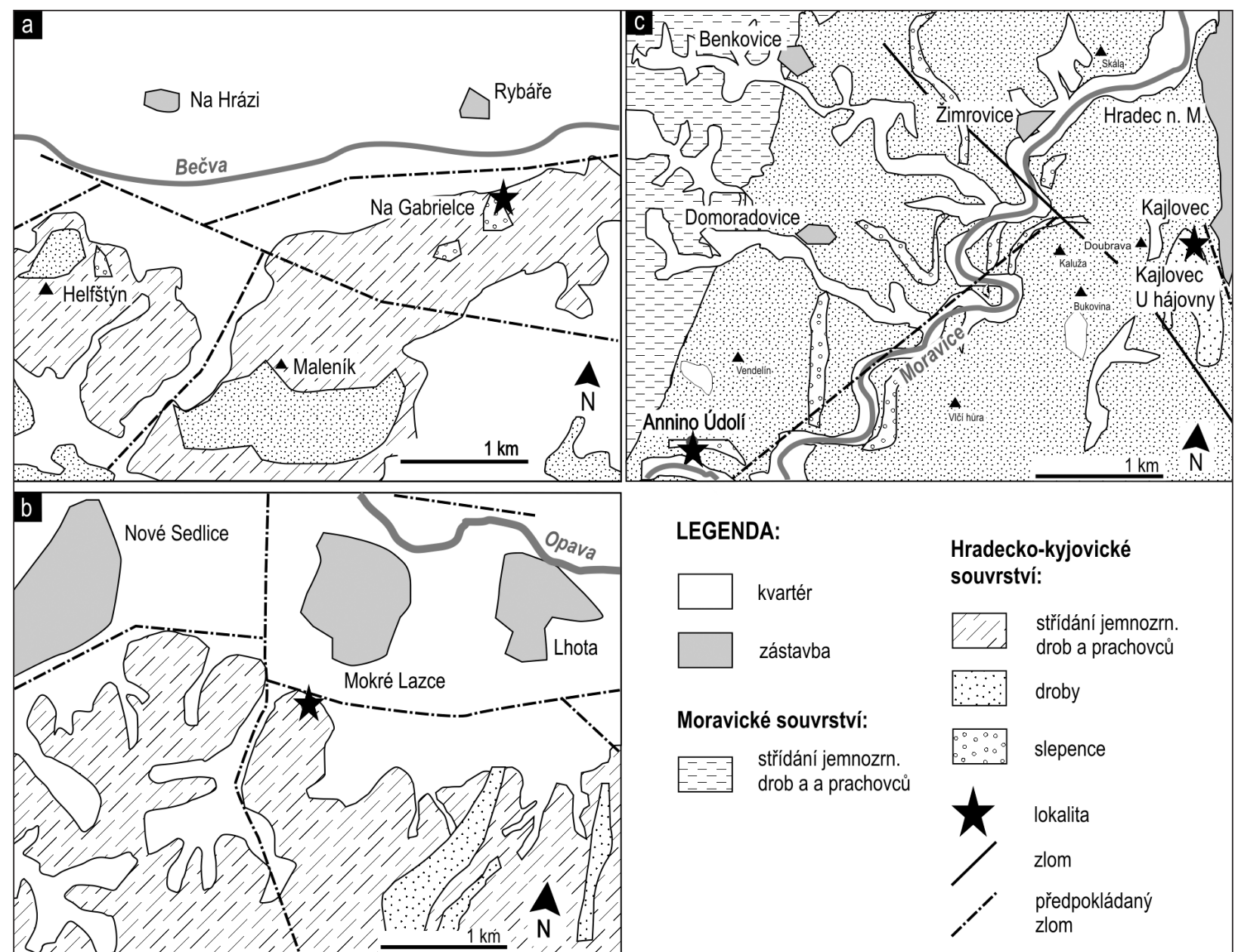

LEGENDA:

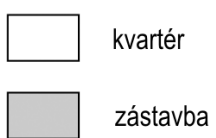

Hradecko-kyjovické souvrství:

střídání jemnozrn. drob a prachovců

droby

Moravické souvrství:

střídání jemnozrn. drob a a prachovci

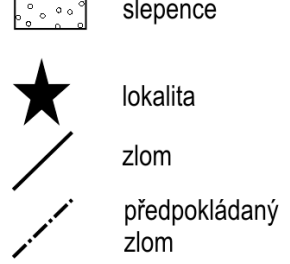

Obr. 2: Schéma geologické situace s vyznačenými lokalitami: a - Maleník „Na Gabrielce“; b - Mokré Lazce; c - Annino Údolí a Kajlovec „U Hájovny“.

Fig. 2: Chart of geological situation with distinguished localities: a - Maleník „Na Gabrielce“; b - Mokré Lazce; c - Annino Údolí a Kajlovec „U Hájovny“. 
stratigraficky zařazena do subzóny Go $\beta_{\text {spi }}$ v blízkosti spodní hranice hradecko-kyjovického souvrství (Kumpera 1976; Lehotský 2008).

\section{Analýza a sedimentační prostředí}

Předmětem faciálního mapování a ichnologického výzkumu byla předpokládaná báze hradeckých vrstev, která na odkryvech a výchozech tvoří několikametrové polohy hrubozrnných drob a slepenců s podřizenými vložkami prachovců a vzácně jílovců (Kumpera 1983) Profily byly studovány na lokalitách Gabrielka u hradu Helfštýn v tektonické kře Maleníku (obr. 2a), Mokré Lazce (obr. 2b), Annino údolí a Kajlovec U hájovny (obr. 2c). $\mathrm{V}$ opuštěném lomu Gabrielka se nachází téměř 8 metrů mocná poloha neuspořádaných slepenců. Je tvořená poloostrohrannými až polozaoblenými valouny i intraklasty s valounovou podpůrnou strukturou a polymodální hrubě zrnitou matrix. Slepence ostře nasedají na podložní těleso neuspořádaných pískovců (obr. 3). Strop slepencového tělesa má erozní kontakt s nadložní vrstvou hrubozrnných pískovců. Směrem do nadloží se vrstvy slepenců a pískovců stř́́dají, přičemž se mocnost vrstev i velikost klastů zmenšuje. Na odkryvu v Annině údolí podložní neuspořádané pískovce ostře přecházejí do 4 metry mocné polohy neusporrádaných slepenců $s$ valounovou podpůrnou strukturou a písčitou polymodální matrix. Směrem do nadloží se opakuje střídání poloh slepenců s pískovci a zmenšování mocnosti vrstev a velikosti klastů. Tento cyklus je ukončen přechodem do poloh prachovito-jílových drob. V drobách lze identifikovat texturní prvky jako jsou pozitivní gradace, šikmé zvrstvení a laminace vyjádřené $\mathrm{T}_{\mathrm{ab}}$ a $\mathrm{T}_{\mathrm{bcd}}$ intervaly Boumovy sekvence. V odkryvu u obce Mokré Lazce bylo na profilu o celkové mocnosti 7,8 metrů identifikováno 39 vrstev. Jílovo-písčité jemnozrnné, střednozrnné i hrubozrnné droby zde tvoří až 1,6 metru mocná lavicovitá tělesa obsahující intraklasty a s patrnou pozitivní gradací, která přechází do paralelního zvrstvení, místy i do šikmého, což je vyjádřitelné intervaly $\mathrm{T}_{\mathrm{ab}}$ a $\mathrm{T}_{\mathrm{abc}}$ Boumovy sekvence. Směrem do nadloží lze pozorovat asymetrické střídání středně mocných vrstev jemnozrnných drob s normální gradací, paralelním i šikmým zvrstvením intervalů $\mathrm{T}_{\mathrm{abc}}$ a $\mathrm{T}_{\mathrm{bcd}}$ Boumovy sekvence a centimetrových poloh laminovaných prachovců ukončený dalším lavicovitým tělesem drob. Na lokalitě je bohatý výskyt přesličkovité rostliny Archaeocalamites scrobiculatus.

V Kajlovci U hájovny bylo v odkryvu vytvořeném těžbou pokrývačských břidlic zdokumentováno 67 vrstev o celkové mocnosti asi 5 metrů. Při bázi a ve svrchní části profilu jsou zastiženy polohy jemnozrnných drob, ve kterých paralelní a šikmé zvrstvení vytváří intervaly $\mathrm{T}_{\mathrm{bc}}$ a $T_{b c d}$ Boumovy sekvence. Zbytek profilu je tvořen jemně laminovanými jílovitými prachovci, které na vrstevních plochách obsahují hojné proudové a vlečné stopy a také ichnofosilie. Ty jsou zde zastoupeny druhy Dictyodora liebeana, Protopaleodictyon isp. a Nereites missouriensis.

\section{Diskuze}

Sedimenty zastižené na studovaných profilech jsou litologicky i faciálně velmi pestré. Neuspořádané slepence s podpůrnou strukturou klastů a polymodální písčitou matrix a písčitými slepenci faciální třídy A byly transportovány vysokohustotními proudy charakteru úlomkotoků s rychlou finální sedimentací. Neuspořádané pískovce faciální třídy B byly uloženy rychlou sedimentací z turbiditního proudu. Droby faciální tř́dy C byly transportovány a ukládány turbiditními proudy různé hustoty. Charakteristická je pro ně přítomnost texturních prvků

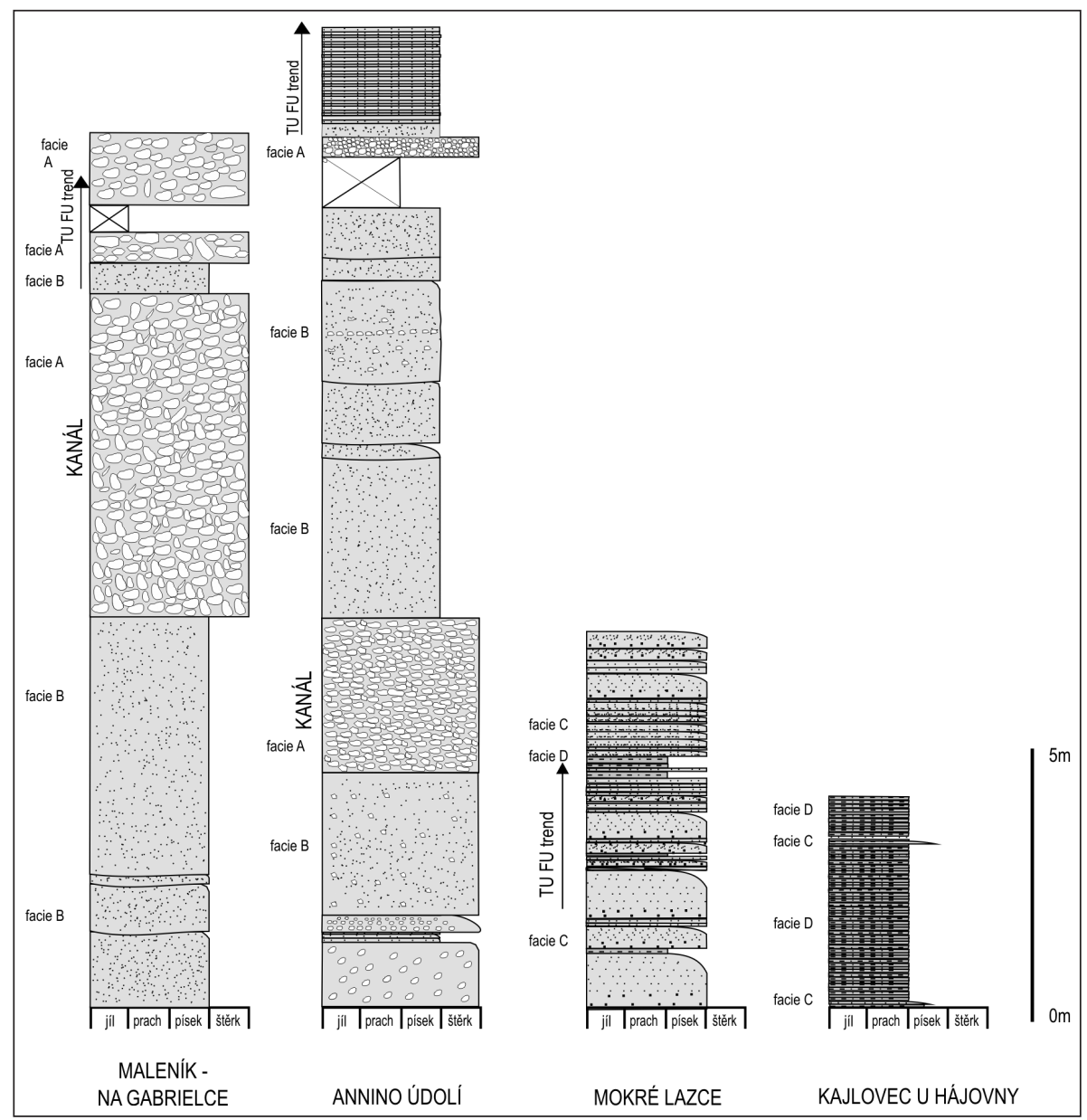

Obr. 2: Schéma geologické situace s vyznačenými lokalitami: a - Maleník „Na Gabrielce“; b Mokré Lazce; c - Annino Údolí a Kajlovec „U Hájovny“.

Fig. 2: Chart of geological situation with distinguished localities: a - Maleník „Na Gabrielce“; b - Mokré Lazce; c - Annino Údolí a Kajlovec „U Hájovny“. 
vyjádřitelných intervaly Boumovy sekvence a závalky intraklastů. Prachovce faciální trídy D a jílovce faciální tř́idy E byly transportovány a ukládány nízkohustotními turbiditními proudy s pomalou sedimentací (Pickering et al. 1986). Na základě litofaciálního studia profilů v zájmové oblasti je možné definovat $\mathrm{v}$ bazálních polohách hradecko-kyjovického souvrství dva typy sedimentačního prostředí: kanálové facie (channels facies) a přelivové facie agradačních valů (overbanks facies). Kanály jsou vyplněny sedimenty hrubozrnných litofaciálních asociací, jako jsou neuspořádané slepence, písčité slepence a hrubozrnná droba. Přelivy agradačních valů jsou tvořeny střednozrn nými a jemnozrnnými drobami s polohami prachovců. Vztah mezi jednotlivými sedimentačními areály je často laterální. Kanály mají depoziční i erozní charakter, zároveň se ve směru od zdrojové oblasti jejich mocnost zmenšuje. Vysoká diverzita zastižených litofacií a jejich vztah v horizontálním a vertikálním profilu naznačují, že bazální polohy hradecko-kyjovického souvrství lze charakterizovat jako turbiditní systém typu II, ve smyslu práce Muttiho et al. (1992). Z výsledků faciální analýzy vyplývá, že v polohách sedimentů zastižených na profilech v lokalitách Gabrielka a Annino údolí lze pozorovat ve svrchních čás tech studovaných profilů směrem do nadloží zřetelné TU a FU trendy (thinning upwards a finning upwards). Tyto sedimentární záznamy dokládají polohu sedimentačního prostředí ve vysokoenergetické, proximální části turbiditního systému, kde gravitační proudy nemají problém s odchylkami topografie dna sedimentační pánve a překážky tvořené preexistujícím depozičním reliéfem odstraní díky své energii erozí (Mutti et al. 1992), to také dokládá hojná prítomnost intraklastů ve studovaných horninách. Profil studovaný na lokalitě Mokré Lazce lze na základě dominance faciálních tříd $\mathrm{C}$ a $\mathrm{D}$ zařadit do střední části turbiditního vějíre a hrubozrnného turbiditního systému (Bouma 2000). Vysokohustotní i nízkohustotní turbiditní proudy, které distribuovaly na studovaném profilu uložené sedimenty, zde měly převážně depoziční charakter. Textura sedimentů zastižených $\mathrm{v}$ odkryvu může reflektovat dynamické změny probíhající mezi zdrojovou oblastí a stř̌ední částí turbiditního vějíře, a to na základě přítomností intervalů $\mathrm{T}_{\mathrm{abc}}$ a $\mathrm{T}_{\mathrm{bcde}}$ Boumovy sekvence (Bouma 1962), nebot jednotlivé intervaly jsou sedimentárním záznamem generovaným koncovými členy těchto procesů (Pickering et al. 1989). Naprosto odlišné sedimentární prostředí je zastiženo na lokalitě Kajlovec U hájovny. Charakter zde určených facií spolu s texturami doloženými na studované lokalitě vedou k závěru, že studovaný profil byl situován $\mathrm{v}$ prostředí klidné sedimentace. Jsou zde zastiženy vrstvy velmi jemně zvrstvených prachovců faciální tř́ídy D s ostrou spodní i svrchní hranicí, které lze definovat jako konturity (Kukal 1986) a poloha pozitivně gradovaného jemnozrnného pískovce faciální tř́́dy C (Pickering et al. 1989). Jednalo se o areál vystavený neustálému působení dnových konturových proudů, který byl epizodicky dotován koncovými členy turbiditních proudů, které ukládaly sedimenty ve vzdálenějších oblastech výnosového vějíře. Přítomnost nereitové ichnofacie na lokalitě je charakteristická pro uloženiny distálních nízkohustotních turbiditů, které jsou typické pro prostor umístěný daleko za agradačními valy (overbanks) a přechodné pásmo mezi vnějším vějírem a samotnou pánví (Buatois - Mángano 2011). Dle Boumy (2000) lze studovaný profil označit jako jemnozrnný turbiditní systém.

Faciálně je bazální část hradecko-kyjovického souvrství v ostrém kontrastu s vikštejnskými vrstvami, které jsou stratigraficky nejvyšším členem podložního moravického souvrství (Bábek et al. 2001). Náhlá změna z př̀evažujících jemnozrnných facií distálních turbiditů do hrubozrnné báze hradeckých drob je vysvětlována druhou fází zvýšeného př́sunu hrubozrnné sedimentace, mající charakter proximálních gravitačních proudů, která se udála ve svrchním visé. Tyto sedimenty byly transportovány a ukládány do někdejší předpolní pánve pravděpodobně od jihozápadu (Hartley - Otava 2001). Na studovaných profilech ve směru JZ-SV je sice zřejmý pokles proximálních a nárůst distálních znaků, celkově charakter turbiditního systému zůstává proximální a hrubozrnný ve smyslu Kukala (1986) a Boumy (2000). Litofaciální studium profilů potvrzuje přechod od konglomerátových a hrubozrnných litofaciálních asociací $\mathrm{k}$ asociacím střednozrnným a jemnozrnným $\mathrm{v}$ předpokládaném směru transportu sedimentů do předpolní kulmské pánve v nejvyšším visé. Na studovaných profilech jsou patrné TU a FU trendy, které se asymetricky opakují. Tyto sekvence jsou sedimentárním záznamem změny $\mathrm{v}$ depozičním režimu, která byla diktována tektonicky a je spojována s kolapsem variského orogénu ve svrchním visé, jak popisují Hartley a Otava (2001). V těchto podmínkách se zřejmě jen velmi problematicky mohly zaznamenat a zachovat fosilní projevy života. K tomu by podle Seilachera (2007) bylo nutné, aby prostředí bylo epizodicky zasaženo přínosem většího množství substrátu, pod kterým se stopy po činnosti organismů mohly zakonzervovat. Dále se na depozici podílely proudy, které měly charakter úlomkotoků, ve kterých byly klasty transportovány nadnášením v plastické směsi vody s jílovo-písčitým sedimentem (Lowe 1982).

\section{Závěr}

V rámci báze hradecko-kyjovického souvrství bylo vyčleněno pět základních litofacií: litofacie slepencová, litofacie písčitých slepenců, litofacie hrubozrnných drob, litofacie střednozrnných drob a litofacie laminovaných jemnozrnných drob a prachovců. Tyto litofacie byly na studovaných profilech zastiženy $\mathrm{v}$ litofaciálních asociacích: konglomerátové, slepencovo-pískovcové a v litofaciální asociaci laminovaných pískovců a prachovců. Na základě společenstva nalezených a popsaných ichnofosilií byla určena nereitová ichnofacie. Podle určených litofacií a litofaciálních asociací lze bazální polohy hradecko-kyjovického souvrství označit za proximální turbidity a turbiditní systém jimi tvořený za hrubozrnný, ve kterém byl sediment transportován a ukládán úlomkotoky, vysokohustotními turbiditními proudy, nízkohustotními turbiditními proudy a konturovými proudy. Faciálně se bazální část hradecko-kyjovického souvrství jeví být v ostrém kontrastu s nejvyššími polohami vikštejnských vrstev podložního moravického souvrství, které jsou za- 
stiženy na lokalitách Olšovec a Hrabůvka. Ty jsou řazeny k faciální třídě D (Bábek et al. 2004), u níž jsou všechny popsané charakteristiky týkající se litologie i mechanismu sedimentace antagonistické $\mathrm{k}$ trídám $\mathrm{A}$ a $\mathrm{B}$ tvořícím faciální asociace na studovaných profilech blízkých spodní hranici hradecko-kyjovického souvrství. Zjištěný rozpor je sedimentárním záznamem přeložení zdrojové oblasti snosu v důsledku komprese, které byla vystavena kulmská pánev ve svrchním visé (Kumpera - Martinec 1995).

\section{Poděkování}

Autoři děkují recenzentưm prof. Mgr. O. Bábkovi, Dr. a RNDr. J. Otavovi, CSc. za věcné a inspirujicí připomínky.

Literatura

Bábek, O. - Mikuláš, R. - Zapletal, J. - Lehotský, T. - Pluskalová, J. (2001): Litofacie a fosilní stopy turbiditního systému viižní části moravského souvrství jesenického kulmu, Český masiv. - Geologické výzkumy na Moravě a ve Slezsku v roce 2000, 2-5.

Bábek, O. - Mikuláš, R. - Zapletal, J. - Lehotský, T. (2004): Combined tectonic-sediment suplly-driven cycles in a Lower Carboniferous deep-marine foreland basin, Moravice Formation (Czech Republic). - Journal of Earth Sciences 93, 241-261.

Bouma, A. (1962): Sedimentology of some flysch deposits: A graphic approach to facies interpretation. - Elsevier, 168 str.

Bouma, A. (2000): Coarse-grained and fine-grained turbidite systems as end member models: applicability and dangers. - Marine and Petroleum Geology 17, 137-145.

Buatois, L. A. - Mángano, M. G. (2011): Ichnology. Organism-substrate interaction in space and time. Cambridge University Press. 358 str.

Gilíková, H. - Maštera, L. - Otava, J. (2003): Charakteristika spodnokarbonských klastických sedimentů na mapovém listu 25-123 Hranice. - Geologické výzkumy na Moravě a ve Slezsku v roce 2003, 44-47.

Hartley, A. J. - Otava, J. (2001): Sediment provenance and dispersal in a deep marine foreland basin: the Lower Carboniferous Culm Basin, Czech Republic. - Journal of the Geological Society, 137-150.

Kukal, Z. (1986): Základy sedimentologie. - Academia. 466 str.

Kumpera, O. (1966): Pohyb materiálu a nástin faciálního vývoje svrchního visé na Moravě a ve Slezsku. - Sborník vědeckých prací Vysoké školy báňské v Ostravě, Řada hornicko-geologická, 12, 138, 31-50.

Kumpera, O. (1971): Faunistické lokality a přehled fauny hradeckého souvrství. - Sborník vědeckých prací Vysoké školy báňské v Ostravě, Řada hornicko-geologická, 17, 281, 129-141.

Kumpera, O. (1976): Stratigrafie spodního karbonu jesenického bloku (2. část: Kulmská souvrství a jejich stratigrafické ekvivalenty). Moravické souvrství. - Sborník vědeckých prací Vysoké školy báňské v Ostravě, Řada hornicko-geologická, 1, 419, 141-163.

Kumpera, O. (1983): Geologie spodního karbonu jesenického bloku. - Knihovna Ústředního Ústavu geologického, 59, 172 str.

Kumpera, O. - Martinec, P. (1995): The development of the Carboniferous accretionary wedge in the Moravian-Silesian Paleozoic Basin. - Journal of Czech Geological Society, 40, 12, 49-66.

Lehotský, T. (2008): Taxonomie goniatitové fauny, biostratigrafie a paleoekologie jesenického a drahanského kulmu. - MS, di sertační práce, PřF MU Brno.

Lowe, D. R. (1982): Sediment gravity flows: II. Depositional models with special reference to the deposits of high-density turbidity currents. - Journal of Sedimentary Petrology, 52, 279-297.

Mutti, E. - Davoli, G. - Segadelli, S. - Cavalli, C. - Carminatti, M. - Stocchi, S. - Mora, S. - Andreozzi, M. (1992): Turbidite Sandstones. - Instituto di Geologia Universta di Parma, 275 str.

Patteisky, K. (1929): Die Geologie und Fossilführung der mährisch-schlesischen Dachschiefer und Grauwackenformation. Naturwissenschaftlichen Verein in Troppau, 354 str.

Pickering, K. - Stow, D. - Watson, M. - Hiscott, R. (1986): Deep water facies, processes and models: a review and classifications scheme for modern and ancient sediments. - Earth-Science Reviews, 23, 2, 75-174.

Pickering, K. - Hiscott, R. - Hein, F. (1989): Deep marine environments. Clastic sedimentation and tectonics. - Earth Science Reviews, 416 str.

Purkyňová, E. (1988): Makroflóra kyjovického souvrství moravskoslezského kulmu a její stratigrafický význam. - Časopis Slezského Muzea, A, 27, 77-86.

Seilacher, A. (2007): Trace fossils analysis. - Springer-Verlag, 226

Zapletal, J. - Dvořák, J. - Kumpera, O. (1989): Stratigrafická klasifikace kulmu Nízkého Jeseníku. - Věstník Ústředního ústavu geologického 64, 4, 243-250. 